\title{
THE RATIONALIZATION OF PRODUCTION OF MAGNESIUM ALLOY DROP FORGINGS USING FEM SIMULATION REGARDING FORGING PROCESS
}

\author{
Mária Kapustová, Jozef Bílik
}

Original scientific paper

In this paper a method of precision die forging without flash of magnesium alloy AZ31 is described. This method brings material and energy savings compared to common method of forging with flash. Computer simulation of technological process of forging has an important role for development of progressive methods of precision die forging. The forging of $\mathrm{Mg}$ alloy in closed die described in this paper was verified using program MSC.SuperForge. Experiment of forging without flash of lever-shaped forged piece from magnesium alloy AZ31 was successfully performed at laboratory conditions. Final drop forging has no folds or other defects on its surface, which is confirmed by correct selection of forging temperature $400{ }^{\circ} \mathrm{C}$ and semi-product shape. Achieved results of the experiment will be important for working team of technologists at introducing forging without flash regarding non-ferrous drop forgings to production practice.

Keywords: closed die; computer simulation; flash; laboratory experiment; magnesium alloy; precision forging

\section{Racionalizacija proizvodnje otkivaka od legure magnezija dobivenih kalupnim kovanjem primjenom FEM simulacije u postupku} kovanja

Izvorni znanstveni članak U radu se opisuje metoda preciznog kovanja u kalupu bez plamena legure magnezija AZ31. U usporedbi s uobičajenom metodom kovanja s plamenom, ova metoda štedi material i energiju. Računalna simulacija tehnološkog postupka kovanja ima važnu ulogu u razvoju naprednih metoda preciznog kovanja. Kovanje legure Mg u zatvorenom kalupu, opisano u ovom radu, verificirano je primjenom programa MSC.SuperForge. Eksperiment kovanja bez plamena otkivka u obliku šipke od legure magnezija AZ31 uspješno je proveden u laboratorijskim uvjetima. Dobiveni otkivak nema nabora ili drugih oštećenja na površini zbog pravilnog izbora temperature kovanja od $400{ }^{\circ} \mathrm{C}$ i oblika polu-proizvoda. Postignuti rezultati eksperimenta bit će važni za radnu grupu tehnologa kod uvođenja u proizvodnju kovanja bez plamena otkivaka dobivenih kalupnim kovanjem.

Ključne riječi: laboratorijski eksperiment; legura magnezija; plamen; precizno kovanje; računalna simulacija; zatvoreni kalup

\section{Introduction}

At present the major part of die forges produces forged pieces using the technology of open die forging. By this method die forgings with flash are manufactured. As the flash is a necessary technological waste of material, of course it increases the consumption of used material, depending on complexity of forged piece shape. It is common practice that with regard to very complex shapes of forged pieces, flash represents from $30 \%$ to $50 \%$ of forging weight. The more complex the shape of a drop forging, the bigger the flash and also the higher the material costs for production. A new, progressive technology of forgings production using precision forging brings rationalization of forged pieces production. In forges the most widely used is application of precision forging using closed dies.

With regard to the technology of drop forgings production in closed die, a principle applies that the semiproduct volume is equal to the volume of a forged piece. Therefore it is necessary to prepare a very precise volume of semi-product, as only a small plus deviation of metal surplus from $1 \%$ to $3 \%$ is permissible. This small surplus of material must be dislocated to designed container, which is most commonly a hole (gab) in a forging tool. Precision forging in closed die enables to manufacture a forging without flash in a more economical way, i.e. with considerable material savings. Thus produced forged pieces meet requirements for high dimensional accuracy and surface quality $[1 \div 5]$.

Global research of die forging technology regarding magnesium alloys was aimed at production of $\mathrm{Mg}$ drop forgings in open dies at the beginning.
Principle of this production method is shown in Fig. 1 where a drop forging with flash is illustrated. This research was performed in the Czech Republic as a cooperation of a university and a drop forge and is described in article [6]. At present a research is being developed with regard to precision die forging of magnesium alloys which is very important for automotive industry. A significant role at processing of production technology designs for drop forgings made of $\mathrm{Mg}$ alloys has high-quality simulation software designed for simulation of hot bulk forming $[7 \div 10]$.
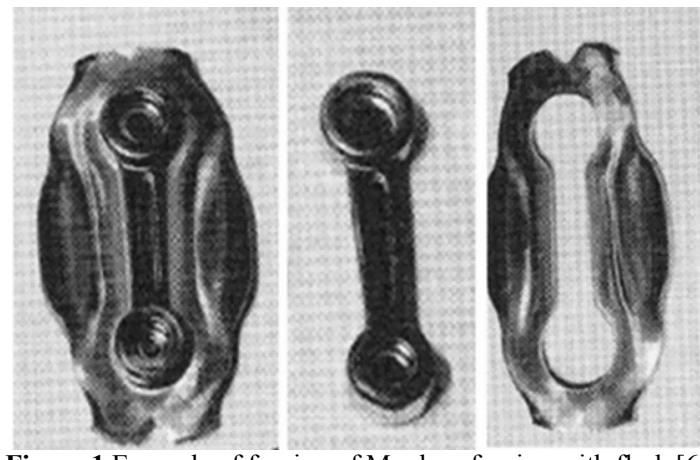

Figure 1 Example of forging of $\mathrm{Mg}$ drop forging with flash [6]

\section{Experiment of precision forging in closed die \\ 2.1 Description of drop forging shape and material}

Technological process of forgings production in closed die has certain limitations in light of shape complexity of forgings. Using this technology it is possible to manufacture forgings with simple rotational or longitudinal shapes only (e.g. rings, flanges, wheels, 
levers). Therefore a lever-shaped forged piece was designed for research purposes, its shape and dimensions are illustrated in Fig. 2. At designing of drop forging shape the standards and principles for closed dies (bevels, radii, wads, etc.) were respected $[2,4,5]$.

Magnesium alloys are the lightest structural material with the highest ratio of $R_{\mathrm{m}} / \rho$ (tensile strength / density). They are characterized by their high strength and low density. It is difficult to form the magnesium alloys at cold temperatures therefore these are usually formed at warm temperatures only. Magnesium alloy type AZ31 is an alloy with good plastic properties $[11 \div 13]$. This alloy shows also good formability at high temperatures, as well as proper machinability and weldability. Heat treatment is not appropriate for the mentioned alloy as it is not able to be hardened. Magnesium alloy AZ31 intended for forming is mostly treated by forging at temperatures from 300 to $400{ }^{\circ} \mathrm{C}$, extruding at $300 \div 480{ }^{\circ} \mathrm{C}$ and by rolling at the temperature interval of 340 to $440{ }^{\circ} \mathrm{C}$ in order to produce forgings, extruded bars and rolled metal sheets $[6,10,14]$.
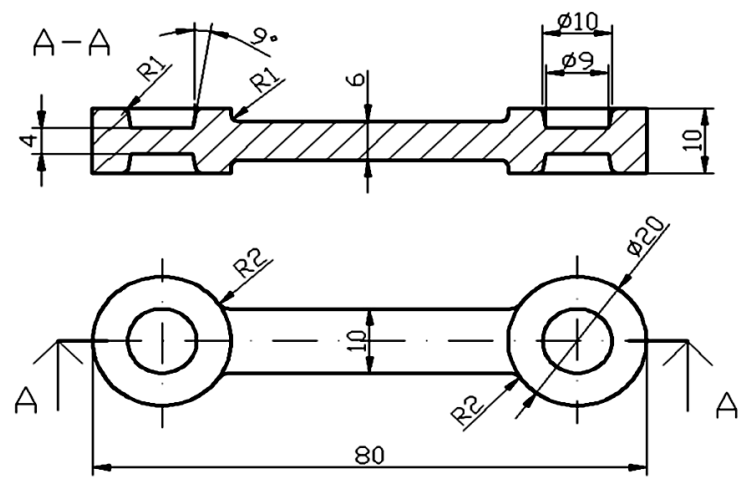

Figure 2 Shape and dimensions of forging "Lever"

Table 1 Chemical composition of $\mathrm{Mg}$ alloy AZ31 (wt\%)

\begin{tabular}{|l|c|c|c|c|c|c|c|}
\hline Element & $\mathrm{Al}$ & $\mathrm{Mn}$ & $\mathrm{Zn}$ & $\mathrm{Cu}$ & $\mathrm{Fe}$ & $\mathrm{Si}$ & $\mathrm{Mg}$ \\
\hline Content & 2,8 & 0,24 & 0,72 & $<0,0005$ & 0,003 & 0,01 & $\mathrm{Bal}$ \\
\hline
\end{tabular}

Tab. 1 specifies chemical composition of alloy AZ31B, which was applied to production of drop forging Lever. Alloying additives increase strength, ductility and corrosion resistance. Oversized Al content aggravates formability at warm and cold temperatures, zinc with $1,5 \%$ content improves strength and formability the most, and $\mathrm{Mn}$ improves corrosion resistance.

\subsection{Preparation of semi-product for forging experiment}

For purposes of die forging experiment regarding a forged piece Lever made from magnesium alloy AZ31, a one-cavity closed die was manufactured from tool steel STN 419552 (Mat. No.1.2343). In order to perform the experiment, one-cavity closed die was designed, which does not provide the possibility to preform the workpiece. Final shape of the forged piece will be forged at one stroke of mechanic press. Perfect production (without any defects) of the forged piece Lever required to design optimal shape and dimensions of workpiece with precise volume, as well as to meet a condition of simple inserting of the material into lower die part.

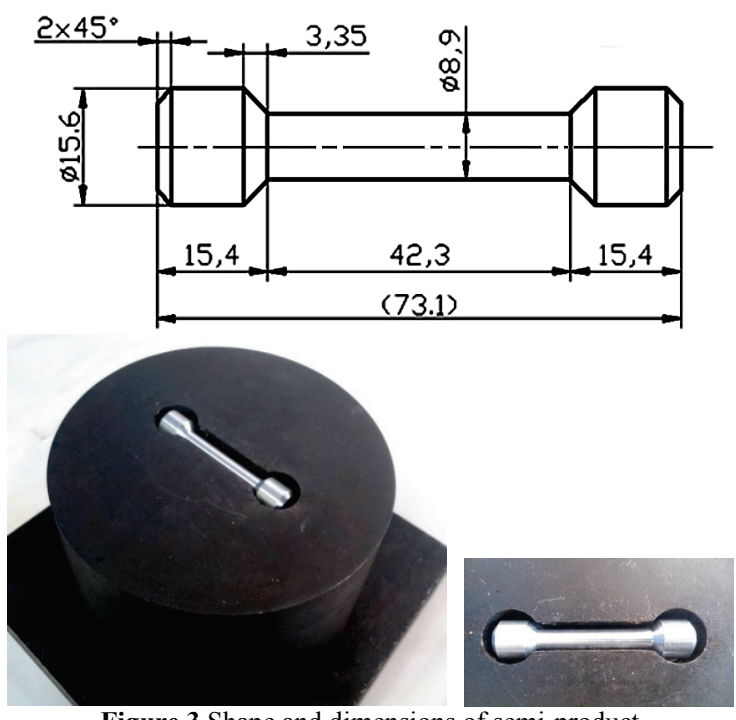

Figure 3 Shape and dimensions of semi-product

Designed semi-product with shape of ideal forging blank is illustrated in Fig. 3 and initial microstructure of magnesium alloy type AZ31 is shown in Fig. 4.

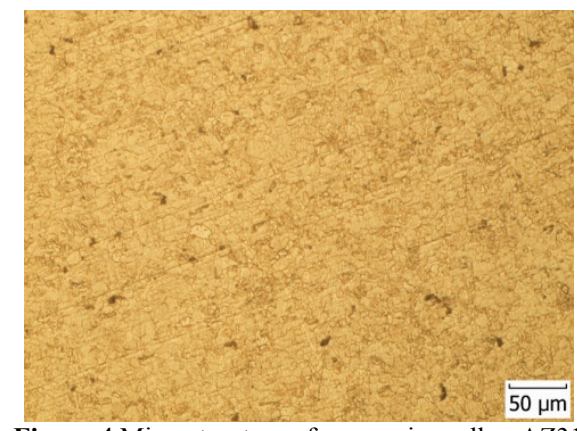

Figure 4 Microstructure of magnesium alloy AZ3

\section{FEM simulation of material plastic flow in closed die 3.1 The phases of the FEM analysis of forging process}

When using Finite Element Method (FEM), the area deformed by forming is separated to finite amount of elements with particular shape and each element has its own approximation. In order to perform areas tasks, a triangular element and approximation function of linear or cubic multi-nominal type are chosen. In the area of bulk forming for a calculation with the help of FEM method mostly volume elements (3D-elements) are used. The FEM method using volume elements is called FVM (Finite Volume Method). The principles of these methods are described in detail in listed literature $[15 \div 17]$.

Balance equations are prepared for particular elements and a system of differential equations will develop. After solving the above mentioned equations, we may achieve results of strain, deformation and temperature fields in a formed body and to follow the flow of solid-plastic or elastic-plastic bodies $[4,5,15]$. Numeric analysis of forming processes uses Eq. (1-2) for calculation of effective strains $\varphi_{\text {ef }}$ and effective stresses $\sigma_{\text {ef. }}$.

$\varphi_{\text {ef }}=\frac{\sqrt{2}}{3} \cdot \sqrt{\left|\varphi_{1}-\varphi_{2}\right|^{2}+\left|\varphi_{2}-\varphi_{3}\right|^{2}+\left|\varphi_{3}-\varphi_{1}\right|^{2}}$, 


$$
\sigma_{\text {ef }}=\sqrt{\frac{1}{2}\left(\left|\sigma_{1}-\sigma_{2}\right|^{2}+\left|\sigma_{2}-\sigma_{3}\right|^{2}+\left|\sigma_{3}-\sigma_{1}\right|^{2}\right)}
$$

In order to mathematically express the plastic flow of material with hardening, a relation according to authors' Levy-Misses Eq. (3) is used.

$\frac{\varphi_{1}-\varphi_{2}}{\sigma_{1}-\sigma_{2}}=\frac{\varphi_{2}-\varphi_{3}}{\sigma_{2}-\sigma_{3}}=\frac{\varphi_{3}-\varphi_{1}}{\sigma_{3}-\sigma_{1}}=\frac{3}{2} \frac{\varphi_{\mathrm{ef}}}{\sigma_{\mathrm{ef}}}$,

where: $\varphi_{1}, \varphi_{2}, \varphi_{3}$ - principal strains, $\sigma_{1}, \sigma_{2}, \sigma_{3}$ - principal stresses.

Reliability of results achieved by FEM simulation depends on correctness of definition of input parameters. Numeric simulation of forming processes usually consists of the following three phases:

Pre-processing - preparation phase which includes preparation of models, i.e. inserting of geometric models in supported format from CAD system. All marginal input conditions and selection of elements, material parameters, machine parameters, etc. are entered.

Processing - phase of calculations using FEM method.

Post-processing - output phase of software which enables to depict achieved results of FEM simulation.

Computer simulation enables to better understand the principles of forging process and mainly follow the plastic flow in die cavity. In this way defects of incorrect flow folds or unfilled places in die cavity - are detected.

Reliability of FEM analysis of forging process in closed die and its results depends on correctly determined input parameters in preparation phase of simulation process $[18 \div 21]$.

\subsection{Post-processing results of program SuperForge}

Correctness of the design of technological forging process was verified through the simulation programme MSC SuperForge. The mentioned software belongs to CAE systems that are suitable especially for computer simulation of bulk forming processes using FEM or FVM methods. An indisputable advantage of this software is a virtual display of the forging process and possibility to optimize the technological parameters prior to the production of forging tool.
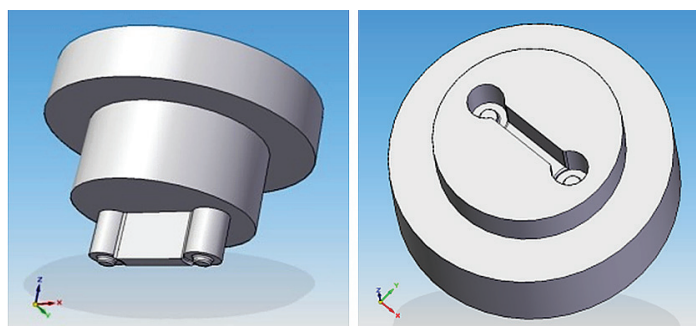

Figure 5 Models of functional parts of forging tool

It enables 2D and 3D simulation and direct inserting of CAD models in STL and DFX formats. For the numeric simulation purposes the models of functional die parts were created using CAD program Solid Edge- the models of forging tool are represented in Fig. 5.

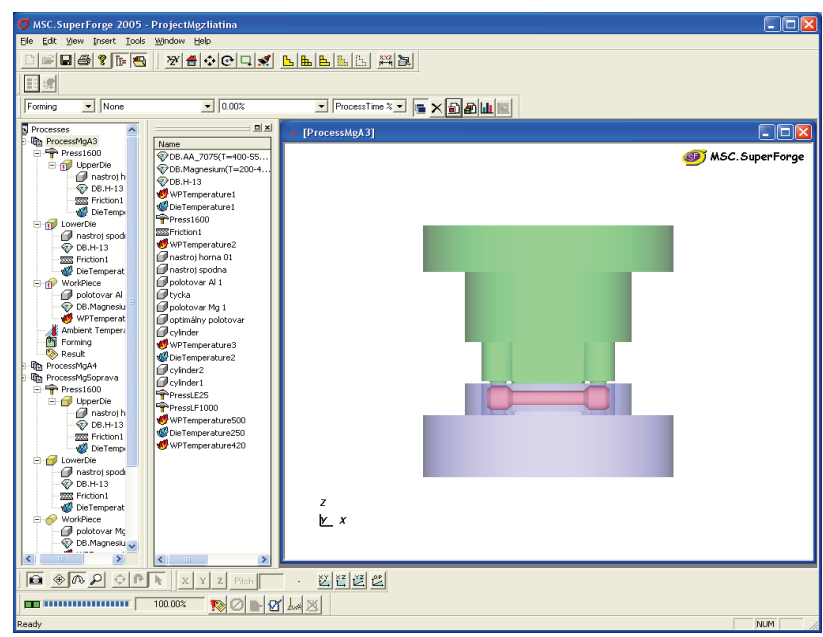

Figure 6 Program MSC.SuperForge - user environment

This program is characterized by its user environment with three dialog windows that are shown in Fig. 6. In order to start a forging simulation of forged piece Lever it is necessary to properly define the input data - these data were set as follows:

- $\quad$ process: closed die forging

- forging machine: mechanical press

- material of workpiece: Magnesium Alloy

- material of tool: ASTM A $681(\mathrm{H} 13)$

- temperature of workpiece: $400{ }^{\circ} \mathrm{C}$

- temperature of tool: $250{ }^{\circ} \mathrm{C}$

- coefficient of friction: 0,2

- workpiece element size: $1 \mathrm{~mm}$

The value of coefficient of friction was selected pursuant to recommendation of various authors already cited in this article $[19 \div 21]$. In order to obtain reliable numeric analysis of die forging process using FEM method, correct meshing of selected workpiece is important. Accuracy of this numeric method depends on the level of discretization of solved area into finite elements and their node points, in which the calculation is performed. The denser is the mesh (network), the higher is the accuracy of problem solution. Simulation software SuperForge offers finite element mesh with element 3D pentahedrons (6-noded) illustrated in Fig. 7.

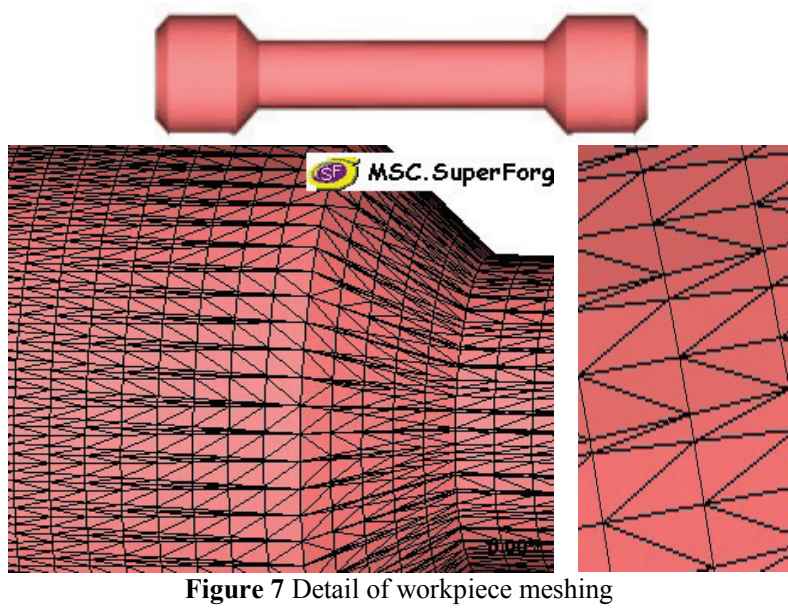

Numeric simulation of forging process as shown in Fig. 8 confirmed correct material plastic flow in closed 
die cavity. No folds or other visible defects appeared on the surface of final forged piece Lever. Semi-product of ideal forging blank shape was designed correctly. The results of post-processing, i.e. output phase of simulation process are the temperature fields in drop forging illustrated in Fig. 9. The highest temperatures were achieved in drop forging heads, i.e. in the area of wad creation, where the material was deformed by pressure the most.
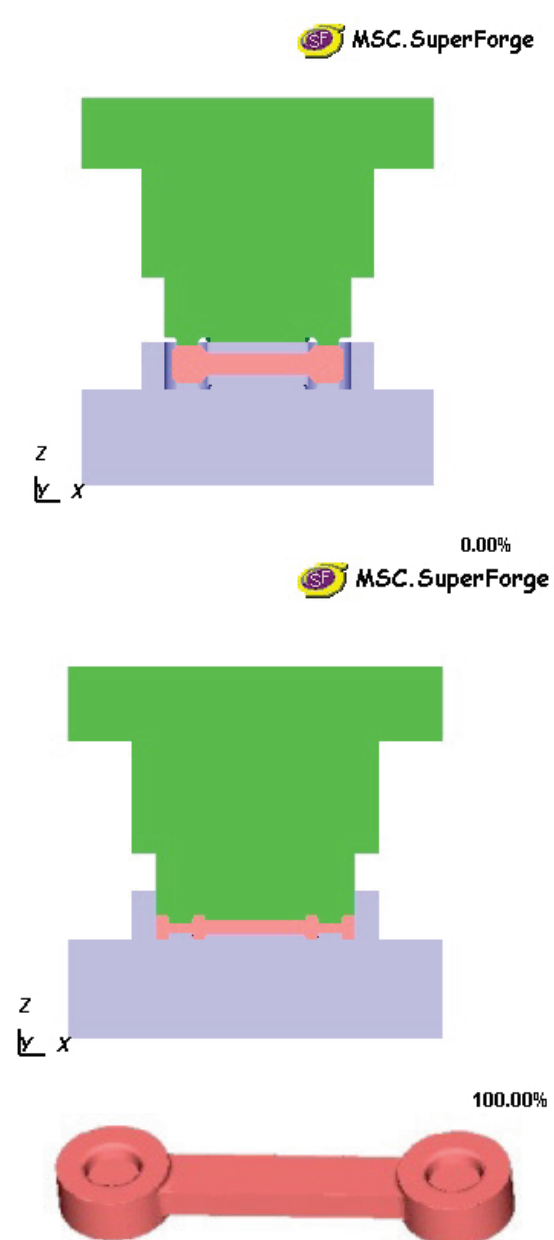

Figure 8 Simulation of material flow in closed die cavity

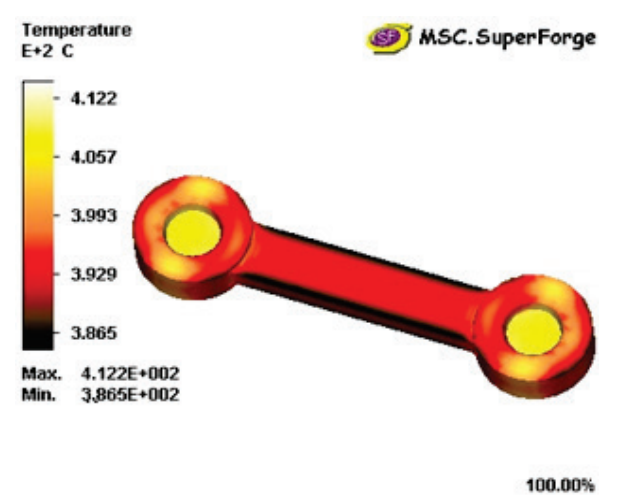

Figure 9 Simulation course of temperature fields in forged piece

Achieved effective plastic strain degrees in the forged piece within phase of its final shape is shown in Fig. 10. The highest values of effective plastic strain degree are in head (i.e. wad area) of the forged piece. Maximal effective plastic strain values achieved by simulation process are comparable to real strain value according to the calculation as follows:

$\varphi_{\max }=\ln \frac{h_{0}}{h_{1}}=\ln \frac{15,6}{4}=\ln 3,9=1,36$

Where: $h_{0}$ - height of semi-product, $h_{1}-$ height of wad (mm).

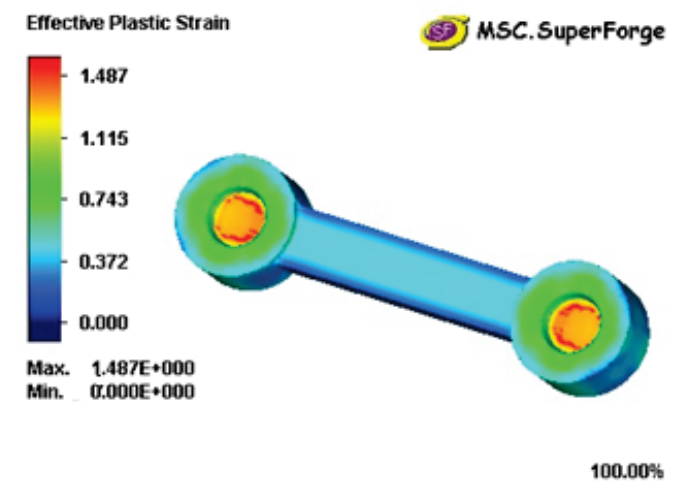

Figure 10 Simulation course of strain degree in forged piece

Colour scale for evaluation of simulation courses shows the highest values of effective plastic strain degree as well as the highest temperatures reached in forged piece during finishing of its shape. The other significant factor of the post-processing phase is a graphic course of the forging force illustrated in Fig. 11. Achieved maximum value of the forging force is important for selection of forging press and production of the forged piece Lever.

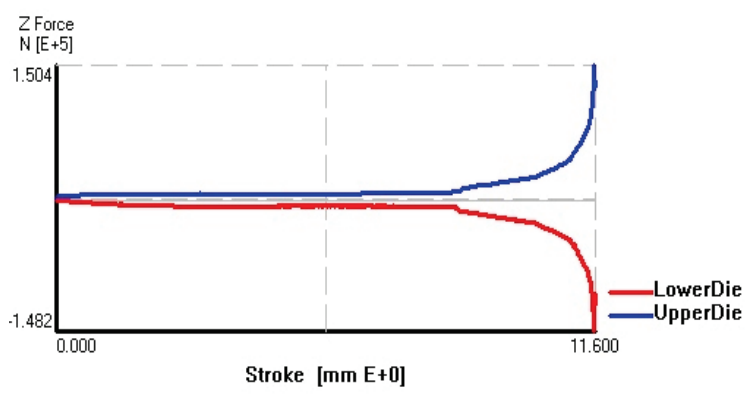

Figure 11 Simulation course of forging force

\section{Precision forging experiment of drop forging}

The experiment of forging in closed die was performed in laboratory conditions. Correct selection of forging press for this experiment depends on force calculation according to the following relation:

$$
F=C \cdot k_{\mathrm{p}} \cdot S(N)
$$

Where: $k_{\mathrm{p}}$ - flow stress of $\mathrm{Mg}$ alloy at forging temperature (MPa), $S$ - plan surface of forged piece $\left(\mathrm{mm}^{2}\right)$ and $C$ coefficient of flow stress increase.

$C=1,53 \cdot\left[\ln \frac{0,47 \cdot d}{r}+m^{2} \cdot \ln \frac{0,47 \cdot d_{1}}{r_{1}}\right] \frac{2 f}{d} \cdot\left|h+m \cdot h_{1}\right|$, 
where:

$m=\frac{d_{1}}{d}$

$f$ - coefficient of friction

$d, d_{1}, r, r_{1}, h, h_{1}-$

dimensions of forged

piece $(\mathrm{mm})$

$f=0,25 ; C=5,1$;

$S=1028,3 \mathrm{~mm}^{2}$

$k_{\mathrm{p}}=30 \mathrm{MPa}$

$F=157,3 \mathrm{kN}$

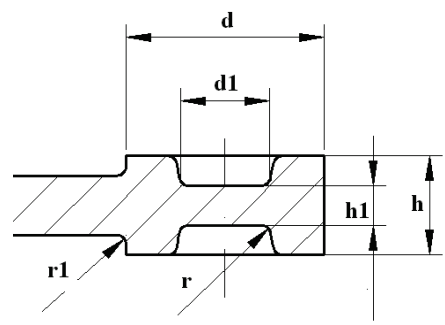

Mechanical press with nominal force $1000 \mathrm{kN}$ was selected out of available forging machines on the basis of calculations of forging force and results of numeric simulation as shown in Fig. 11.

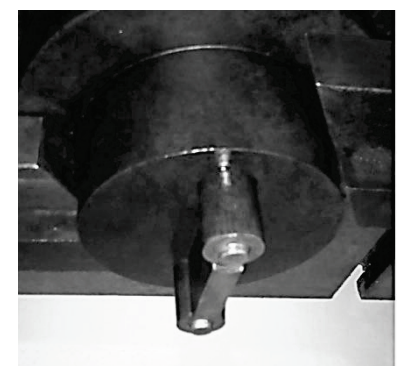

a) upper die

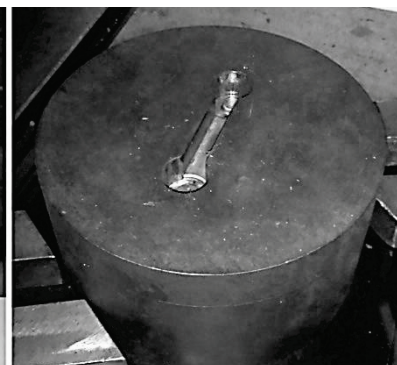

b) lower die

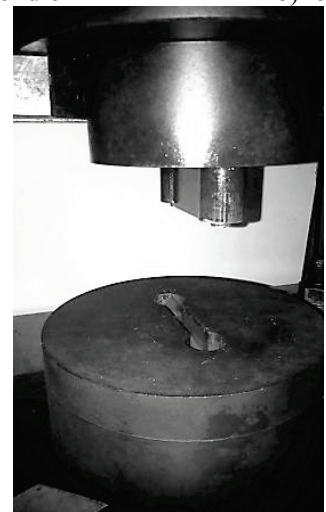

Figure 12 Forging tool determined for experiment of $\mathrm{Mg}$ alloy forging

One-cavity closed die illustrated in Fig. 12 was fixed into work space of the press. Semi-product was heated to forging temperature $400{ }^{\circ} \mathrm{C}$ in electric furnace type Elektro MLW $0-1200{ }^{\circ} \mathrm{C}$. The forging temperature of semi-product was verified by thermometer TESTO 945 which contains contact thermocouple NiCr-Ni with scope of temperatures $200-1370{ }^{\circ} \mathrm{C}$. Final shape of $\mathrm{Mg}$ alloy forged piece Lever made experimentally is shown in Fig. 13.

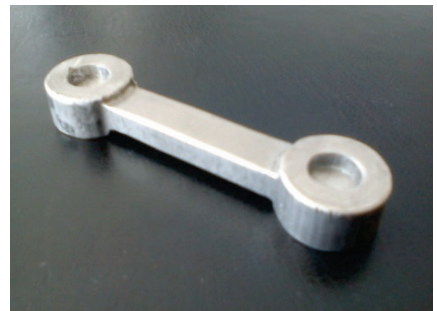

Figure 13 Final shape of Mg alloy drop forging

\section{Conclusion}

The technology of precision forging of magnesium alloy in closed die brings considerable economic profit through material and energy savings. As significant factor for application of new technology into industrial practice is also production price, introduction of closed-die forging without flash is possible because it brings cheaper production of drop forgings. Economy of mentioned technology is mostly influenced by selection of optimal upper forging temperature as well as other technological conditions. However, the proposed technology has a disadvantage - it is appropriate only for lever-shaped and rotary-shaped forged pieces, i.e. for production of simple shaped forged pieces.

FEM simulation of closed die forging process is important for optimization of technological forging parameters, especially forging temperature. Correctly selected upper forming temperature ensures sufficient metal plasticity and perfect filling of die cavity.

Numeric simulation of die forging process of magnesium alloy AZ 31 described in this paper confirmed by correct plastic material flow that the selection of forging temperature $400{ }^{\circ} \mathrm{C}$ was appropriate. Virtual display of plastic flow of $\mathrm{Mg}$ alloy was necessary in order to correctly perform the experiment in laboratory conditions. The simulation programme MSC SuperForge enabled to optimize the semi-product dimensions, as well as the final shape of die cavity. The mentioned optimizations were realized in preparation phase of forged piece production. Through this experiment at selected forging temperature $400{ }^{\circ} \mathrm{C}$ a forged piece without any surface defects was manufactured. Reliability of FEM analysis of forging process in closed die and its results depend on correctly determined input parameters in preparation phase of simulation process.

Although the research of closed-die forging without flash of non-ferrous alloys was performed in laboratory conditions, the same brings valuable information also for the production practice. In case of series production of the forged pieces Lever, the semi-product shape (as Fig. 3 shows) should be manufactured by a more effective method, e.g. cross wedge rolling.

At present the demand for forgings with higher accuracy, i. e. near net shape forgings, is increasing. Further research performed by authors of this paper in this technological area will therefore focus on the influence of forging temperature on accuracy of dimensions and shape, as well as surface quality of magnesium alloy drop forgings. Warm die forging appears as interesting technology for research activities.

\section{Acknowledgements}

The research has been supported by the Scientific Grant Agency of the Slovak Republic (VEGA) within the project No. $1 / 1010 / 16$ and 1/0669/15.

\section{References}

[1] Doege, E.; Bohnsak, B. A. Closed die technologies for hot forging. // Journal of Material Processing Technology. 98, 2(2000), pp. 165-170. 
https://doi.org/10.1016/S0924-0136(99)00194-6

[2] Kapustová, M. Innovations in production trends for drop forging. Scientific Monographs. $1^{\text {st }}$ ed. Köthen: Hochschule Anhalt, 2010.

[3] Douglas, R.; Kuhlmann, D. Guidelines for precision hot forging with applications. // Journal of Material Processing Technology. 98, 2(2000), pp.182-188. https:// doi.org/10.1016/S0924-0136(99)00197-1

[4] Hosford, W.F.; Caddell, R.M. Metal forming: Mechanics and metallurg. New York: Cambridge University Press, 2011.

[5] Altan, T. et al. Cold and hot forging: Fundamentals and applications. // ASM International / Ohio, 2005, pp. 319334.

[6] Greger, M. et al. Experience with forging magnesium alloys. // Kovárenství. 35, (2009), pp. 17-24.

[7] Gontarz, A.; Pater, Z.; Drozdowski, K. Hammer forging process of lever drop forging from AZ31 magnesium alloy. // Metalurgija. 52, 3(2013), pp. 359-362.

[8] Gontarz, A. Theoretical and experimental research of hammer forging process of rim from AZ31 magnesium alloy. // Metalurgija. 53, 4(2014), pp. 645-648.

[9] Skubisz, P.; Sinczak, J.; Bednarek, S. Forgeability of MgAlZn magnesium alloys in hot and warm closed forging, // Journal of Materials Processing Technology. 177, 13(2006), pp. 210-213.

[10] Chan, C. F. et al. The influence of process parameters on forged magnesium alloys. //Materials Science Forum. 437438, (2003), pp. 427-431. https://doi.org/10.4028/www.scientific.net/MSF.437-438.427

[11] Yang, Z. et al. Review on research and development of magnesium alloys. //Acta Metallurgica Sinica. 21, (5) (2008), pp. 313-328. https://doi.org/10.1016/S1006-7191(08)60054-X

[12] Yong, M. S. et al. Evaluation on the formability of magnesium alloy AZ31. // Materials Science Forum. 437438, (2003), pp. 435- 438. https://doi.org/10.4028/www.scientific.net/MSF.437-438.435

[13] Guo, W. et al. Microstructure and mechanical properties of AZ31 magnesium alloy processed by cyclic closed-die forging. // Journal of Alloys and Compounds. 558 (2013), pp. 164-171. https:// doi.org/10.1016/j.jallcom.2013.01.035

[14] Wang, O. et al. Effect of initial grain on mechanical properties of AZ31 alloy during warm forming. // Applied Mechanics and Materials. 217-219, (2012), pp. 2304-2308. https://doi.org/10.4028/www.scientific.net/AMM.217-219.2304

[15] Kobayashi, S.; Oh, S. I.; Altan T. Metalforming and the Finite-Element Method. Oxford: University Press, 1989.

[16] Dixit, P. M.; Dixit, U. S. Modeling of metal forming and machining processes by finite element and soft computing methods. London: Springer Verlag, 2008. p. 590.

[17] Champion, E.R. Finite element analysis in manufacturing engineering. New York: McGraw-Hill,Inc. 1993.

[18] Kapustová, M.; Görögová, I. Application of computer simulation at optimization of technological parameters of precision die forging. // Technical Gazette, 23, 2(2016), pp. 357-361. https://doi.org/10.17559/TV-20140625102450

[19] Plančak, M.; Car, Z.; Kršulja, M. et al. Possibilities to measure contact friction in bulk metal forming. // Technical Gazette. 19, 4(2012), pp. 727-734

[20] Behrens, B. A. Finite element analysis of die wear in hot forging processes. // CIRP Annals Manufacturing Technology. 57, 1(2008), pp. 305-308. https:// doi.org/10.1016/j.cirp.2008.03.087

[21] Lee, R. S.; Jou, J. L. Application of numerical simulation for wear analysis of warm forging die. // Journal of Material Processing Technology. 140, 1-3(2003), pp. 43-48. https://doi.org/10.1016/S0924-0136(03)00723-4

\section{Authors' addresses}

Mária Kapustová, doc. Ing. PhD

Slovak University of Technology in Bratislava, Faculty of Materials Science and Technology, Institute of Production Technologies,

J. Bottu 25, 917 24, Trnava, Slovak Republic maria.kapustova@stuba.sk

Jozef Bílik, doc. Ing. PhD

Slovak University of Technology in Bratislava, Faculty of Materials Science and Technology, Institute of Production Technologies,

J. Bottu 25, 917 24, Trnava, Slovak Republic jozef.bilik@stuba.sk 